University of Nebraska - Lincoln

DigitalCommons@University of Nebraska - Lincoln

Nebraska Cooperative Fish \& Wildlife Research Nebraska Cooperative Fish \& Wildlife Research Unit -- Staff Publications

2010

\title{
A modelling approach to evaluate potential management actions designed to increase growth of white perch in a high-density population
}

\author{
Christopher J. Chizinski \\ TexasTech University, cchizinski2@unl.edu \\ Kevin L. Pope \\ University of Nebraska-Lincoln, kpope2@unl.edu \\ G.R. Wilde \\ Texas Tech University
}

Follow this and additional works at: https://digitalcommons.unl.edu/ncfwrustaff

Part of the Other Environmental Sciences Commons

Chizinski, Christopher J.; Pope, Kevin L.; and Wilde, G.R., "A modelling approach to evaluate potential management actions designed to increase growth of white perch in a high-density population" (2010). Nebraska Cooperative Fish \& Wildlife Research Unit -- Staff Publications. 12.

https://digitalcommons.unl.edu/ncfwrustaff/12

This Article is brought to you for free and open access by the Nebraska Cooperative Fish \& Wildlife Research Unit at DigitalCommons@University of Nebraska - Lincoln. It has been accepted for inclusion in Nebraska Cooperative Fish \& Wildlife Research Unit -- Staff Publications by an authorized administrator of DigitalCommons@University of Nebraska - Lincoln. 


\title{
A modelling approach to evaluate potential management actions designed to increase growth of white perch in a high-density population
}

\author{
C. J. CHIZINSKI \\ Department of Natural Resources, Texas Tech University, Lubbock, TX, USA
}

\section{K. L. POPE}

USGS Nebraska Cooperative Fish and Wildlife Research Unit, School of Natural Resources, University of Nebraska, Lincoln, $N E, U S A$

\author{
G. R. WILDE \\ Department of Biological Sciences, Texas Tech University, Lubbock, TX, USA
}

\begin{abstract}
A deterministic, age-structured population model was developed to simulate potential management scenarios designed to increase growth of individuals (quantified by maximum length) in a hypothetical population of white perch, Morone americana (Gmelin). Four scenarios were developed that included non-selective mortality of adult white perch, increased mortality of age groups most influential on population growth, increased age-0 mortality and inhibiting recruitment after spawning. The greatest increase in maximum length occurred with nonselective adult mortality when population biomass was reduced by $97 \%$; lesser increases in maximum length were achieved with the other management scenarios. Populations returned to their original state after control efforts ceased for each scenario.
\end{abstract}

KEYWORDS: dynamic population model, invasive species, Morone americana, population management.

\section{Introduction}

The white perch, Morone americana (Gmelin), is a euryhaline, semi-anadromous species native to the eastern coast of North America from Nova Scotia, Canada to South Carolina, USA. Intentional stockings have expanded the species' distribution throughout the Great Lakes and Missouri River basins (Hergenrader \& Bliss 1971). Introduced white perch have quickly dominated fish communities in lentic systems (Hergenrader \& Bliss 1971) causing two management concerns. One is predation on and competition with commercial and sport fishes (Schaeffer \& Margraf 1987; Prout et al. 1990). White perch feed on plankton, macroinvertebrates, small fish and fish eggs, thus potentially interfering with the recruitment of native fishes directly through predation and indirectly through competition for shared resources (Madenjian et al. 2000). The second concern, and the subject of this study, is that white perch has a propensity to develop high-density populations of small, slowgrowing fish (Hergenrader \& Bliss 1971; Vrtiska et al. 2003). In its native range, white perch does not display the propensity to form high-density, slowly growing populations and is not a major management concern.

The control and management of problematic species, such as white perch, has become an important task for fishery managers. Although non-selective elimination methods have been effectively used in the past (Simberloff et al. 2005), this is not always a practical strategy. A targeted approach on susceptible ages or life stages may be a more efficient strategy to control or eradicate a problematic species. The Leslie 
matrix (Caswell 2001) has become an important tool in management of a variety of species (e.g. Govindarajulu et al. 2005; Shea et al. 2006) because it can be used to identify life stages that are most susceptible to control, even for species with complex life cycles (Govindarajulu et al. 2005). Additionally, model simulations provide insight into the practicality and effectiveness of alternative management strategies.

The few studies that have modelled the effects of sizedependent mortality on high-density populations of small, slow-growing fish (e.g. Ylikarjula et al. 1999; van Kooten et al. 2007) described the effectiveness of population thinning (i.e. removal of biomass) to alleviate the small body size, but they did not describe the effort necessary to achieve management goals or the long-term consequences of ceasing management activities. The first objective of this study was to develop and parameterise a Leslie matrix (Caswell 2001) using fecundity and survival data (Chizinski 2007) for a high-density white perch population with small, slowgrowing fish, and then use elasticity and loop analyses to identify age groups and vital rates that strongly affect population growth rate. The second objective of this study was to parameterise a deterministic, age-structured population projection model and a linked lengthat-age model to explore the effectiveness of potential management scenarios designed to increase growth of individuals (quantified by maximum length) in hypothetical populations of white perch.

\section{Methods}

\section{Parameter estimation}

Fecundity and adult survival estimates needed for the Leslie matrix were obtained from an assessment of the white perch population in Branched Oak Lake, Nebraska, USA (Chizinski 2007). Survival rates of age-1 and older fish were assumed to be constant and estimated from a catch curve $\left(S_{a}=0.68\right.$; Chizinski 2007). Age- 0 survival of white perch has not been measured. Any single missing element of the Leslie matrix can be estimated if the rate of population growth is known or is assumed to take some value (Vaughan \& Saila 1976). Thus, age-0 survival was estimated using methods described by Vaughan and Saila (1976), with the assumption that the white perch population growth rate $(\lambda)$ was static (i.e. $\lambda=1$ ).

\section{Elasticity and loop analyses}

Following Caswell (2001), the asymptotic population growth rate was assessed as the dominant eigenvalue of the projection matrix. Elasticity analysis (Benton \& Grant 1999; de Kroon et al. 2000) was used to estimate proportional effects of changes in fecundity and survival on $\lambda$. Confidence intervals for the elasticities of fecundity and survival for white perch were estimated empirically using bootstrap methods. One thousand transition matrices were generated, in which elements were randomly drawn from normal distributions with means $(\mu)$ and variances $\left(s^{2}\right)$. Estimates of $\mu$ for fecundity and $\mu$ for survival were taken from mean fecundities and mortalities observed in Branched Oak Lake. The $s^{2}$ of fecundity was calculated as $\sqrt{\mu}$ and the $s^{2}$ of survival was calculated as $\mu(1-\mu)$. Loop analysis, an extension of elasticity analysis (van Groenendael et al. 1994; de Kroon et al. 2000), was used to compare the relative contribution of each age group to the overall population growth rate to assess which age groups were most susceptible to population management. In loop analysis, elasticities must sum to 1 (van Groenendael et al. 1994; Wardle 1998). Matrix analyses and modelling were accomplished using a program written in MATLAB version 7 (Mathworks, Natick, MA USA) and curve fitting was accomplished using Proc NLIN in SAS (version 9.1) (SAS, Cary, NC, USA).

\section{Hypothetical population projection model}

A model that incorporated population structure and growth of individuals in each age group was developed based on data collected from Branched Oak Lake and other white perch populations (Table 1) to assess changes in maximum length in hypothetical populations of white perch subjected to various management scenarios. The model was run at annual time steps $(t)$ to simulate incremental changes in population biomass and length at age $a\left(L_{a}\right)$. Each population was projected into the next time step, $t+1$, by multiplying the fecundity and survival matrix by a vector of the

Table 1. Parameters used in a white perch projection model to simulate responses to potential management scenarios in hypothetical populations

\begin{tabular}{|c|c|c|c|}
\hline Parameter description & Symbol & Value & Source \\
\hline Age-0 survival & $S_{0}$ & $6.17 \times 10^{-5}$ & This study \\
\hline Adult survival & $S_{\text {adult }}$ & 0.68 & Chizinski (2007) \\
\hline $\begin{array}{l}\text { Maximum increment } \\
\text { of growth }(\mathrm{mm})\end{array}$ & $\Delta$ & 45 & Wong (2002) \\
\hline Gonadosomatic index & $G$ & 0.8 & $\begin{array}{l}\text { Jackson \& } \\
\text { Sullivan (1995) }\end{array}$ \\
\hline Mass conversion factor & $\alpha$ & $2.54 \times 10^{-5}$ & Chizinski (2007) \\
\hline Age at maturity (years) & $A_{\text {mat }}$ & 1 & Chizinski (2007) \\
\hline Maximum age (years) & $A_{\max }$ & 7 & This study \\
\hline
\end{tabular}


number of individuals in each age group at time $t$. Known longevity of white perch populations is 510 years (Wong 2002; Chizinski 2007); the midpoint (7 years) was used as the maximum age for the hypothetical populations. The population was initialised with 100 individuals in each age group, and the model was run until the population stabilised.

\section{Individual growth and fecundity}

Somatic growth of white perch was adapted from the framework described by Ylikarjula et al. (1999), which used the energy-allocation model described by Roff (1983). This model assumes that energy available for growth is size dependent (Ylikarjula et al. 1999). Thus, growth follows a linear trajectory prior to sexual maturation with maximum allocation of energy to somatic development. After sexual maturation, energy is devoted to reproduction; thus, energy allocated to somatic growth is diminished, producing an asymptotic growth curve. The length of a fish in age group $a+1\left(L_{a+1}\right)$ was described by:

$$
L_{a+1}=L_{a}+\Delta(t) \quad \text { for } 0 \leq a<a_{\mathrm{m}}
$$

and

$$
L_{a+1}=\frac{L_{a}+\Delta(t)}{\sqrt[3]{1+G}} \quad \text { for } a \geq a_{\mathrm{m}}
$$

where $\Delta$ is the increment of growth at time $t, G$ is the gonadosomatic index (assumed to be constant [Roff 1983]) and $a_{\mathrm{m}}$ is the age at first reproduction. The mass of an individual fish in each age group $\left(W_{a}\right)$ was described by:

$$
W_{a}=\alpha L_{a}^{3}
$$

where $\alpha$ is the mass-length coefficient (Ylikarjula et al. 1999) determined from the mass-length relationship (Chizinski 2007).

Total biomass at time step $t$ determines the degree of intraspecific competition and, thus, the amount of energy available for incremental growth over the next time step. Biomass was described by:

$$
\text { biomass }=\sum_{a=1}^{a_{\max }} W_{a}(t) \times N_{a}(t)
$$

where $N_{a}$ is the number of individuals at age group $a$. The effect of density dependence on incremental growth was modelled using a Beverton-Holt-type functional response (Beverton \& Holt 1957):

$$
\Delta=\left[\frac{1}{1+\left(b_{\text {growth }} \times \text { biomass }\right)}\right] \times \Delta_{\max }
$$

where $b_{\text {growth }}$ is the scaling parameter for densitydependent growth and $\Delta_{\max }$ is the maximum increment of growth in the absence of density dependence. Thus, as biomass increases, incremental increases in length decrease (Ylikarjula et al. 1999).

The number of ova produced by female white perch was assumed to be a function of total length rather than age because the number of ova produced by a female is largely constrained by body capacity (Roff 1992); thus, fecundity of a small female white perch will be less than that produced by a larger but similarly aged white perch. Fecundity estimates were necessary beyond the lengths observed in Branched Oak Lake to model female fecundity across a wide range of lengths. Fecundity-at-length estimates were gathered from published sources (Taub 1969; Bur 1986; Carlander 1997) and fit using a power function to describe fecundity as a function of female length. The number of ova produced in time step $t$ by a fish in age group $a$ were released at the onset of time step $t+1$. Modelling ova produced in this manner ensured that ova production was a function of conditions present during ova development rather than conditions at the time of ova release.

\section{Model initialisation}

The two items required to complete the population projection matrix were age- 0 survival and the fecundity-at-length relationship. The fecundity-at-length relationship was determined from 32 fecundity estimates of white perch encompassing a range of 112 $306 \mathrm{~mm}$ TL. Total length explained $88 \%$ of the variation in fecundity (Fig. 1). The survival rate of the age- 0 white perch in Branched Oak Lake was estimated to be $6.17 \times 10^{-5}$, which is consistent with similar estimates for several freshwater (Wilde \& Durham 2008) and marine (Dahlberg 1979) fishes.

The hypothetical white perch population model was initiated with 800 individuals (100 per age group) with a size structure from a population (Tillery Reservoir, NC; Wong 2002) that exhibited moderately high growth rates $\left(40 \mathrm{~mm} \mathrm{yr}^{-1}\right)$ of age- 2 individuals. First reproduction by white perch was assumed to occur at age 1 (Bur 1986; Chizinski 2007). The population age distribution stabilised within 30 years (Fig. 2). When the model was simulated with the effect of density dependence $\left(b_{\text {growth }}=9.0 \times 10^{-6}\right)$, the population had a biomass of $228 \mathrm{~kg}$ and individual fish had a maximum length of $147 \mathrm{~mm}$ in model year 40 . The 


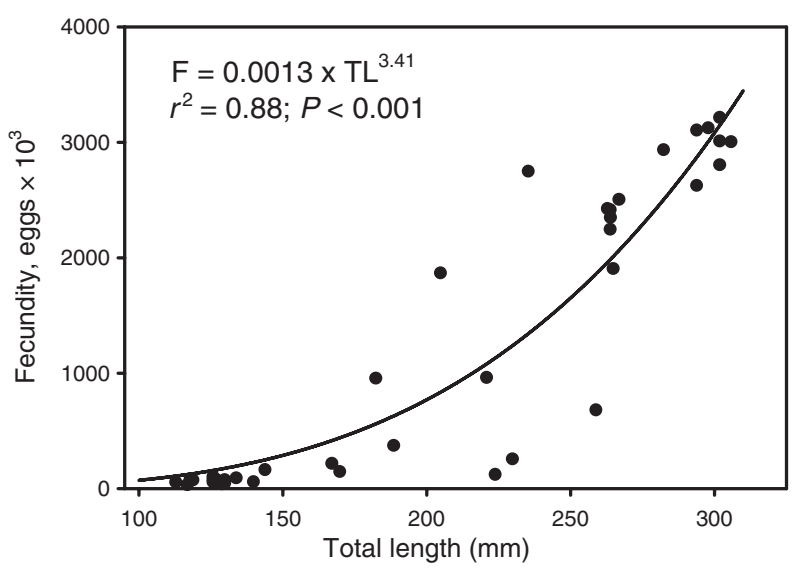

Figure 1. Relationship between mean fecundity (F) and total length (TL) of white perch.
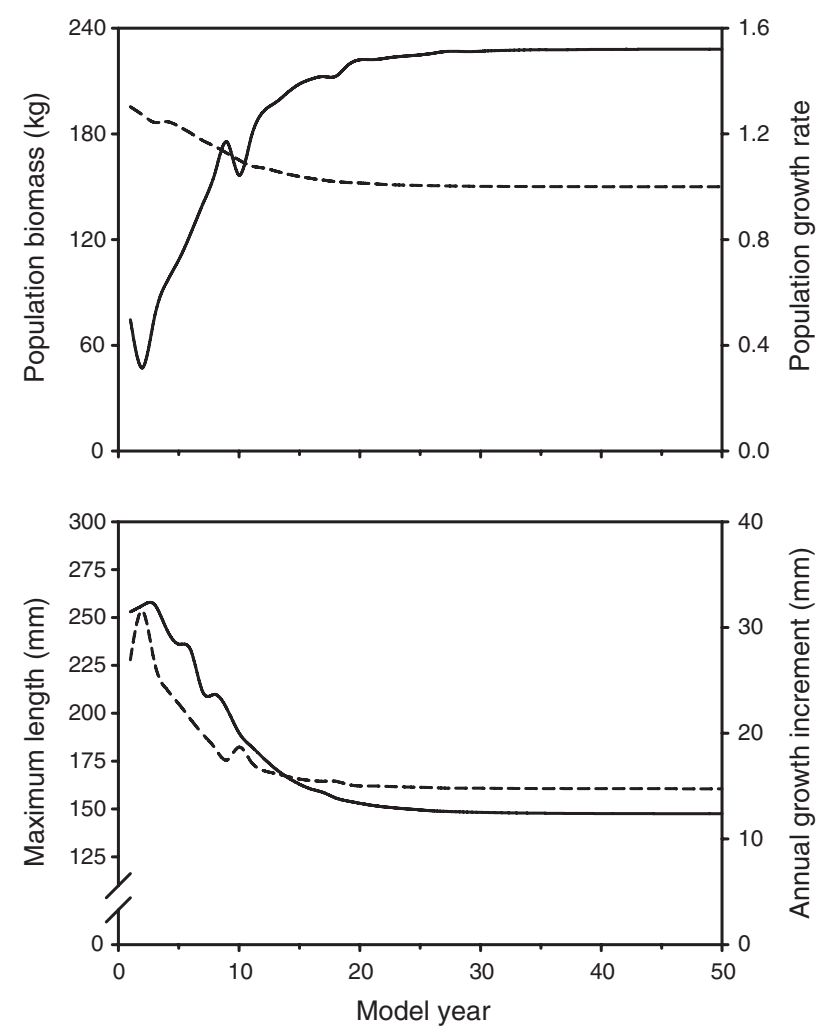

Figure 2. Projected change in population biomass (solid line, top panel), population growth rate (dashed line, top panel), maximum length (solid line, bottom panel) and annual growth increment (dashed line, bottom panel) in a hypothetical white perch population. Estimates were determined using the deterministic projection model.

maximum growth increment for fish under densitydependent resource limitation for the stabilised population was $14.7 \mathrm{~mm} \mathrm{yr}^{-1}$. The maximum length was
$339 \mathrm{~mm}$ when the model was simulated without the effect of density dependence $\left(b_{\text {growth }}=0\right)$.

\section{Simulated management scenarios}

Preliminary deterministic modelling indicated that hypothetical white perch biomass and the body-length relationship stabilised by model year 40 . Thus, the management scenarios (described below) were enacted in model year 41 . The goal was to reduce the effect of density dependence and increase the maximum length of white perch in the hypothetical populations. Increasing the maximum length of individuals within a dense population by thinning (i.e. reduction in population biomass) can require several years of removal effort (Ylikarjula et al. 1999; Amundsen et al. 2007; van Kooten et al. 2007). Thus, all management scenarios were sustained for one white perch generation (viz. 7 years). The metrics used to judge the simulated management scenarios were proportional changes in biomass (biomass in model year 49/biomass in model year 41) and maximum length ( $L_{7}$ in model year $49 / L_{7}$ in model year 41 ).

When managing a population, resource managers must contend with many factors outside their control (e.g. weather, the public, ecological interactions, effectiveness of management action) that affect the realisation of management goals (Choi 2004; Ellis \& Elphick 2007). To incorporate the uncertainty of realising management goals, a random parameter for success was used in two of the management scenarios.

\section{Non-selective adult mortality scenario}

In exploited fish populations, mortality of adult fish includes natural $(M)$ and fishing $(F)$ mortality (Ricker 1975). Manipulations of $M$ by managers are possible, but the control of $F$ is more likely. $M$ was assumed to be constant for adult fish and was held at 0.35 (Chizinski 2007). The effects of $F$ were assumed to be additive to $M$ and assessed from 0.05 to 0.65 in increments of 0.05 . A size-dependent factor was included in the calculation of fishing mortality through the inclusion of a selectivity variable $\left(u_{a}\right)$ described by a logistic function (Brown \& Walker 2004):

$$
u_{a}=\left(1+\mathrm{e}^{\ln (19) \times\left(\left(L_{a}-u 50\right) /(u 50-u 95)\right)}\right)^{-1}
$$

where $u 50$ is the length at $50 \%$ selectivity (i.e. $50 \%$ of the fish at this length were captured) and $u 95$ is the length at $95 \%$ maximum selectivity. Values for $u 50$ and $u 95$ were determined from lengths associated with age groups most susceptible to population management, as 
indicated by elasticity and loop analysis. Fishing mortality was then expressed as the product of $F_{\max }$ and $u_{a}$. Adult survival $\left(S_{a}\right)$ was calculated by:

$$
S_{a}=1-(M+F) .
$$

Non-selective adult mortality was modelled using gear selectivity of $u 50=90 \mathrm{~mm}$ and $u 95=120 \mathrm{~mm}$, meaning that $50 \%$ of $90-\mathrm{mm}$ fish were caught by the gear and $95 \%$ of $120-\mathrm{mm}$ fish were caught.

\section{Age-group management scenario}

To assess the targeted removal of age- 2 and age- 3 fish (the ages that elasticity and loop analyses indicated most influenced population growth; see Results), simulations were run with randomised success of inducing the targeted mortality on age- 2 and age-3 fish. Success was determined by generating a random uniform variable, and if the random variable generated at year $t$ was greater than the level of failure (1 success) the increase in mortality was accomplished; otherwise, mortality of age- 2 and age- 3 fish was 0.32 . The model used simulations of increased age- 2 and age- 3 mortality by $0.17,0.34$ and 0.51 (increases in mortality by 25,50 and $75 \%$ ) at a success of 50,75 and $90 \%$. This method was used on each year $t$ of the management period. Thus, the greater the success, the greater the number of years the age-group management approach was successfully realised. The simulation was repeated for 1000 iterations and the mean and $95 \%$ confidence interval $(\mathrm{CI})$ of the changes in length and biomass were calculated.

\section{Age-0 mortality scenario}

Predation on age- 0 white perch may have the potential to alter white perch size structure. To estimate the predation necessary on age- 0 white perch to reduce the presumed density-dependent limitation on growth, simulations were run in which age- 0 white perch mortality was increased across nine increments that represented $10 \%$ incremental decreases in survival (i.e. $10-90 \%$ ). These simulations assumed that adult mortality did not change with the increase in age- 0 mortality.

\section{Recruitment failure scenario}

Another potential management scenario would be failure of recruitment of white perch through habitat manipulation. This management practice has been suggested for the control of common carp, Cyprinus carpio (L.) (Shields 1958; Brown \& Walker 2004). For example, a drop in water levels in a reservoir just after spawning could desiccate the eggs (Shields 1958). However, this management practice is rarely $100 \%$ effective and may be of limited success with broadcast spawners such as white perch (Zuerlein 1981; Salek et al. 2001); nevertheless, it warrants investigation. The potential effectiveness of recruitment failure was modelled in a similar way to that described in the age-group management scenario. The success $(50,75$ and $90 \%)$ of the habitat manipulation for effectively causing recruitment to fail was randomly drawn from a uniform distribution and, if the random variable generated at year $t$ was greater than the level of failure (1 - success), recruitment was totally prevented (age- 0 survival $=0$ ) in year $t$, otherwise age-0 survival was $6.17 \times 10^{-5}$. The simulation was repeated for 1000 iterations and the mean and $95 \%$ confidence interval (CI) of the changes in length and biomass were calculated.

\section{Post-management population response}

The response of the white perch populations to cessation of management efforts was simulated to provide insight about likely population response after control methods were stopped and to determine whether population thinning was sufficient to establish populations with moderately fast growth. Management efforts began in model year 41 and continued for a period of 7 years, as in the adult mortality scenario, assuming $F_{\max }=0.60, \quad u 50=90 \mathrm{~mm}$ and $u 95=$ $120 \mathrm{~mm}$. The effect of the management scenario was then removed and post-management responses of white perch maximum length and biomass were simulated (model year 49 onward) until each white perch population stabilised.

\section{Results}

\section{Elasticity and loop analyses}

Simulations with the elasticity matrix indicated that survival rates of age- 0 (mean $=0.257 ; 95 \% \mathrm{CI}=$ $0.212-0.370$ ) and age-1 fish (mean $=0.178 ; 95 \%$ CI $=0.158-0.229)$ consistently had the greatest effect on the population dynamics of white perch. The three elements of the elasticity matrix that contributed most to population growth rate were age- 0 , age- 1 and age- 2 survival (Table 2), which together accounted for $56 \%$ of the contribution to $\lambda$. Similarly, loop analysis indicated that age- 2 and age- 3 white perch dominated population dynamics (Fig. 3). This suggests that management strategies directed towards younger age 
Table 2. Elasticity analysis of reproduction and survival rates in the white perch projection matrix. Reproduction and survival estimates are from the white perch population in Branched Oak Lake, Nebraska, USA (Chizinski 2007)

\begin{tabular}{ccc}
\hline Age & Reproduction & Survival \\
\hline 0 & 0 & 0.2483 \\
1 & 0.0598 & 0.1885 \\
2 & 0.0610 & 0.1274 \\
3 & 0.0468 & 0.0807 \\
4 & 0.0319 & 0.0488 \\
5 & 0.0204 & 0.0284 \\
6 & 0.0125 & 0.0159 \\
7 & 0.0075 & 0.0084 \\
8 & 0.0044 & 0.0040 \\
9 & 0.0025 & 0.0014 \\
10 & 0.0014 & 0 \\
\hline
\end{tabular}

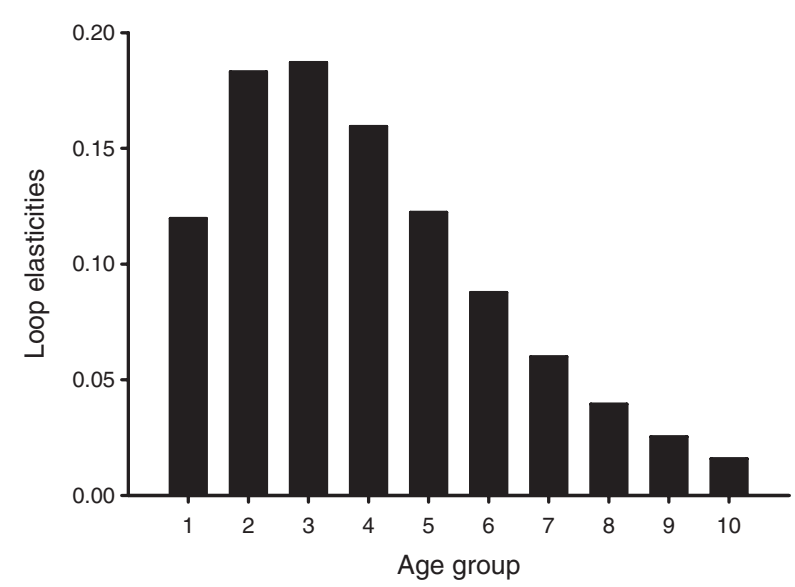

Figure 3. Contribution (loop elasticities) of age groups to population growth for white perch in Branched Oak Lake, Nebraska.

groups have the greatest chance to successfully realise management objectives.

\section{Non-selective adult mortality scenario}

Simulations of non-selective adult mortality indicated that the greatest decrease in biomass and the greatest increase in maximum length of the white perch occurred at the maximum adult mortality of 0.65 (Fig. 4). With $M$ fixed at $0.35, F$ needed to exceed 0.15 , which resulted in a biomass reduction of $33 \%$, to achieve an increase in maximum length greater than $10 \%$.

\section{Age-group management scenario}

Simulations of age- 2 and age- 3 management indicated that an increase in maximum length of the white perch

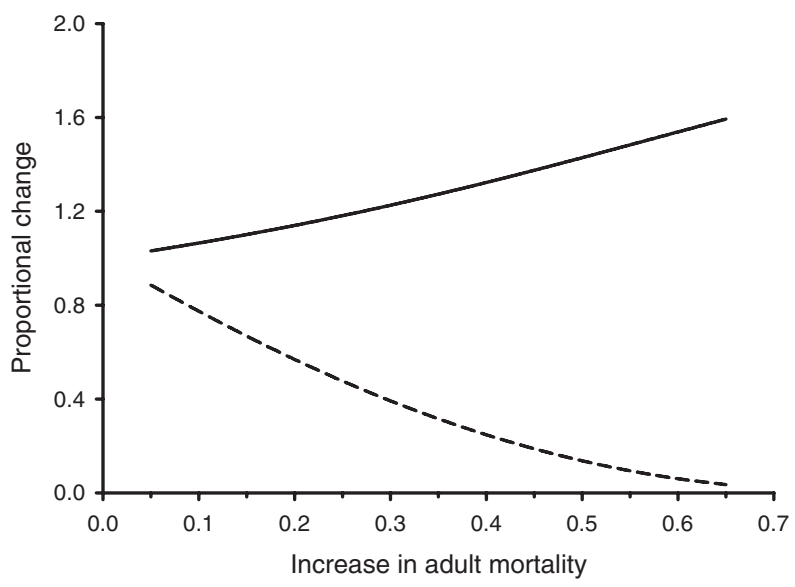

Figure 4. Projected change in white perch maximum length (solid line) and biomass (dashed line) with increases in total mortality (i.e. nonselective adult mortality scenario) in a hypothetical white perch population. Estimates were determined using the deterministic projection model. The change is estimated as the length or biomass at the end of the management period divided by initial length or biomass.

depended on increases in mortality and relative success of completing age-group management. The greatest increase in maximum length of white perch was associated with the greatest increase in mortality and chance of success. The greatest increase in maximum length was $32 \%$, the result of increasing age- 2 and age3 mortality by 0.51 and a $90 \%$ success rate. Increases in maximum length of white perch by $10 \%$ or more could be attained by $50 \%$ or greater reductions in survival of age- 2 and age- 3 fish even with moderate success (Table 3).

\section{Age-0 mortality scenario}

Simulations of reduced juvenile survival indicated that an increase in maximum length of the white perch depended on increases in age- 0 mortality (Fig. 5). The

Table 3. Mean ( $95 \%$ CI) change in maximum length with 25,50 and $75 \%$ reduction in survival of age- 2 and age- 3 white perch from a hypothetical population when success of the age-group management scenario over the course of 7 years is 50,75 and $90 \%$

\begin{tabular}{llll}
\hline \multirow{2}{*}{$\begin{array}{l}\text { Management } \\
\text { scenario }\end{array}$} & $50 \%$ & \multicolumn{3}{c}{ Success } \\
\cline { 2 - 4 } $\begin{array}{l}25 \% \\
\text { reduction }\end{array}$ & $1.04(1.03-1.08)$ & $1.07(1.05-1.09)$ & $1.08(1.07-1.09)$ \\
$\begin{array}{l}50 \% \\
\text { reduction } \\
\begin{array}{l}75 \% \\
\text { reduction }\end{array}\end{array}$ & $1.10(1.06-1.17)$ & $1.16(1.13-1.21)$ & $1.19(1.162-1.210)$ \\
\hline
\end{tabular}




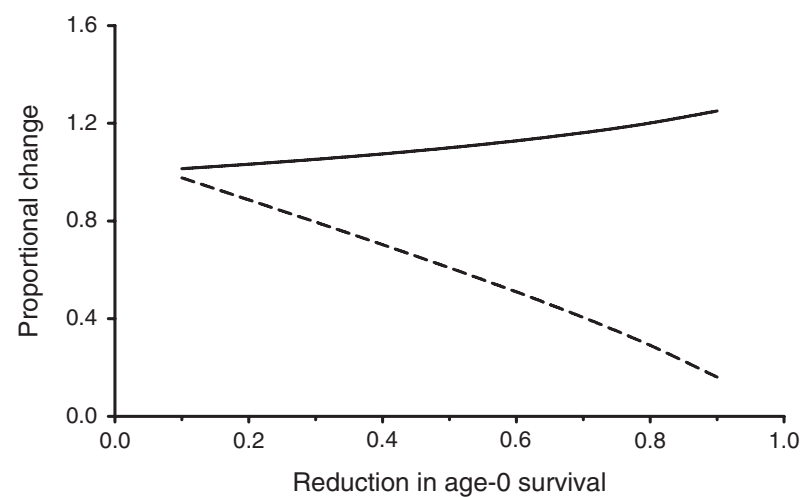

Figure 5. Projected change in white perch maximum length (solid line) and biomass (dashed line) with reductions in age- 0 survival (i.e. age- 0 mortality scenario) in a hypothetical white perch population. Estimates were determined using the deterministic projection model. The change is estimated as the length or biomass at the end of the management period divided by initial length or biomass.

greatest increase in maximum length and decrease in population biomass of white perch was associated with the greatest reduction in survival. Reducing age-0 survival by $90 \%$ (age- 0 survival $=6.17 \times 10^{-6}$ ) resulted in a $25 \%$ increase in maximum length. Reducing age- 0 survival by $10 \%$ had the least effect on the maximum length of the white perch, inducing only a $1 \%$ increase in maximum length. A $10 \%$ increase in maximum length required at least a $50 \%$ increase in age- 0 mortality.

\section{Recruitment failure scenario}

Simulations of recruitment failure indicated that an increase in maximum length of the white perch depended on the success of completing recruitment failure management. The greatest increase in maximum length of white perch was associated with the greatest increase in the chance of successfully preventing recruitment. An $11 \%$ (mean $=11.2 \%$; $95 \%$ CI $=6.0-22.7 \%$ ) increase in white perch maximum length could be achieved when achievement of recruitment failure was $50 \%$. Increasing the chance of success of recruitment failure to 75 or $90 \%$ caused substantially greater increases in maximum length (mean $=20.0 \%, 95 \%$ CI $=13.5-31.6 \%$ for $75 \%$ chance of recruitment failure; mean $=26.4 \%, 95 \%$ CI $=20-32 \%$ for $90 \%$ chance of recruitment failure).

\section{Post-management population response}

The non-selective mortality scenario with $F_{\max }=0.60$ produced the greatest increase in maximum length of white perch. For this scenario, white perch maximum length was $250 \mathrm{~mm}$ in model year 49 and continued to increase following the management period to $278 \mathrm{~mm}$ in model year 53 (Fig. 6). Population biomass immediately increased following the management period, suggesting the initiation of a return of the population to the dense state after the final removal effort was completed. White perch maximum length ultimately returned to the original pre-management length, producing a stabilised population in nearly 30 years. Similar patterns were observed for all management scenarios after efforts to increase mortality ceased; the period required for populations to stabilise to the original state was shorter for populations that had lesser increases in maximum length at the conclusion of management efforts.

\section{Discussion}

The inverse relationship between population density and individual growth, assumed to result from densitydependent food availability, is a long-recognised pattern (Amundsen et al. 2007) that is especially evident in fishes (e.g. Pierce et al. 2003; Imre et al. 2005; Simonović \& Nikolic 2007). The white perch model in this study used this relationship between growth rate and population density to predict incremental growth of individuals in response to changes in population density. Despite being initiated with

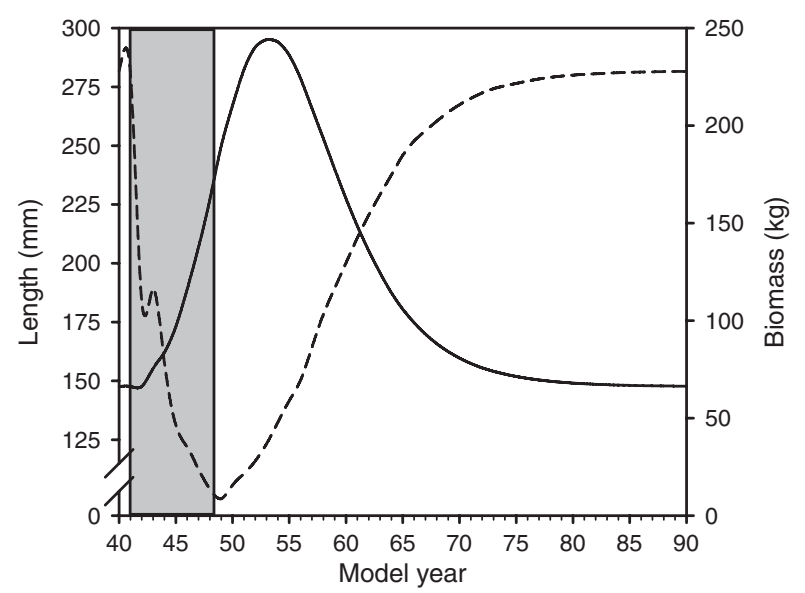

Figure 6. Projected change in maximum length (solid line) and biomass (dashed line) in a hypothetical white perch population to a period of hypothetical management (grey box) with a targeted maximum fishing mortality of 0.60 and gear selectivity of $u 50=90 \mathrm{~mm}$ and $u 95=120$. See text for parameter descriptions. Model initiation was accomplished in model years $1-40$ to allow the population to stabilise (see Fig. 3). Removal efforts were initiated in model year 41 and continued through model year 48 . 
lengths from a population with moderately fast growth rates, the white perch projection model accurately predicted the maximum length of the white perch in Branched Oak Lake (mean length of age-7 white perch was $148 \mathrm{~mm}$ TL in Branched Oak Lake [Chizinski 2007] and length of age-7 white perch at equilibrium in this model was $147 \mathrm{~mm}$ ).

The management simulations highlight the importance of mortality in regulating maximum size of white perch. In the white perch population in Branched Oak Lake, adult survival was estimated to be 0.68 (Chizinski 2007), age-0 survival was $6.17 \times 10^{-5}$ (this study) and maximum length was $148 \mathrm{~mm}$ (Chizinski 2007). In a population of white perch in Pawnee Lake, Nebraska (located $14 \mathrm{~km}$ south of Branched Oak Lake), adult survival was estimated to be 0.39 (Chizinski 2007), age0 survival was $3.73 \times 10^{-5}$ (C. Chizinski, unpublished data) and maximum length was $216 \mathrm{~mm}$ (Chizinski 2007). The survival rate of white perch in Pawnee Lake was $57 \%$ of that observed in the high-density white perch population in Branched Oak Lake, which corresponded with white perch from Pawnee having a maximum length $46 \%$ greater than white perch from Branched Oak Lake.

High-density populations of small, slow-growing fish also have negative effects on fish communities (Klemetsen et al. 2002). The density-dependent food limitation imposed upon the high-density populations affects other organisms sharing the same food resources. For example, after the introduction of Arctic charr, Salvelinus alpinus L., in Takvatn Lake, Norway, brown trout, Salmo trutta L., abundance decreased rapidly and remained low after the Arctic charr formed a dense, stunted population (Klemetsen et al. 2002). After managers reduced the density of Arctic charr, Klemetsen et al. (2002) observed increased charr and brown trout growth and suggested that the increased growth was caused by reduced competition for food resources.

Thinning is a common management practice for the alleviation of high-density populations of small, slowgrowing fish (Alm 1946; Burrough \& Kennedy 1979; Donald \& Alger 1989). Donald and Alger (1989) observed increased growth rates with greater exploitation of slowly growing brook trout, but the increase was less than expected. Several authors have noted that, at high densities, a large perturbation is required to realise substantial shifts in growth rates of individuals (Burrough \& Kennedy 1979; Donald \& Alger 1989; Klemetsen et al. 2002). Simulations of white perch response to increased mortality also indicated that a large perturbation (biomass reduction $\geq 90 \%$ ) was necessary for a substantial (i.e. $>50 \%$ ) increase in white perch maxi- mum length, and that a moderate perturbation would produce a change in maximum length that was probably impossible to detect in the field. Simulations also showed that white perch maximum length continued to increase while management efforts were sustained, but the population quickly returned to the pre-removal state after removal efforts ceased.

These results imply that a simple thinning of a population is not sufficient to create and sustain a population with moderately fast growth, but rather that the ecological factors that caused the population to form a high-density population (e.g. minimal mortality from predation) must be addressed. The results suggest that management designed to create a self-sustaining population containing fish across a larger size-structure from a high-density population requires a two-phase strategy. The first phase is substantial biomass reduction to alleviate the intense density-dependent food limitation. The second phase is to alter the ecological conditions that induced the formation of a high-density population, primarily the establishment of greater predation pressures to reduce survival [i.e. biocontrol (Malakoff 1999; Everett 2000)] of younger, smaller individuals.

Although the model in this study investigated management scenarios required to alleviate a dense population of white perch, the model also can simulate management scenarios required to eradicate this problematic species. The current model highlights a potential difficulty in the eradication of white perch. Under intense management efforts, the degree of density-dependent resource limitation was reduced and individuals responded with increased growth rates and, therefore, larger fish. Larger females are capable of producing more eggs; the largest age- 7 females can produce more than 300000 eggs. Such high fecundities make eradication of this species difficult with targeted removal efforts. Effective removal of white perch from a body of water would require the successful eradication of all individuals. Otherwise, females escaping the removal would grow rapidly without the constraint of food limitation and produce a greater number of eggs during the upcoming breeding season.

The control and management of problematic species is becoming a greater task for managers (Hulme 2006). Population models provide a tool to find susceptible age or size groups and assess various management or control scenarios. Future research will be required to test the management practices that could efficiently remove this amount of biomass. The models in this study predicted effective management strategies; these strategies need to be implemented and evaluated to test model predictions and fine-tune the models. 


\section{Acknowledgments}

We thank F. C. Sanchez and J. R. Stittle for assistance in the field and laboratory. B.W. Durham and C. L. Higgins provided comments on an earlier draft of this manuscript. This work was partially supported by funds from Federal Aid in Sport Fish Restoration, project F-172-R, administered by the Nebraska Game and Parks Commission. The Nebraska Cooperative Fish and Wildlife Research Unit is jointly supported by a cooperative agreement among the U.S. Geological Survey, the Nebraska Game and Parks Commission, the University of Nebraska, the U.S. Fish and Wildlife Service and the Wildlife Management Institute.

\section{References}

Alm G. (1946) Reasons for the occurrence of stunted fish populations with special reference to perch. Report from the Institute of Freshwater Research, Drottningholm 25, 1-146.

Amundsen P.A., Knudsen R. \& Klemetsen A. (2007) Intraspecific competition and density dependence of food consumption and growth in Arctic charr. Journal of Animal Ecology 76, 149-158.

Benton T.G. \& Grant A. (1999) Elasticity analysis as an important tool in evolutionary and population ecology. Trends in Ecology \& Evolution 14, 467-471.

Beverton R.J.H. \& Holt S.J. (1957) On the Dynamics of Exploited Fish Populations. Fisheries Investigation Series 2, Vol. 19, London: UK Ministry of Agriculture and Fisheries, $544 \mathrm{pp}$.

Brown P. \& Walker T.I. (2004) CARPSIM: stochastic simulation modelling of wild carp (Cyprinus carpio L.) population dynamics, with applications to pest control. Ecological Modelling 176, 83-97.

Bur M.T. (1986) Maturity and fecundity of the white perch, Morone americana, in western Lake Erie. Ohio Journal of Science 86, 205-207.

Burrough R.J. \& Kennedy C.R. (1979) The occurrence and natural alleviation of stunting in a population of roach, Rutilus rutilus (L.). Journal of Fish Biology 15, 93-109.

Carlander K. (1997) Handbook of Freshwater Fishery Biology: Volume 3. Life History Data on Ichthyopercid and Percid Fishes of the United States and Canada. Ames, IA: Iowa State University Press, 397 pp.

Caswell H. (2001) Matrix Population Models, 2nd edn. Sunderland, MA: Sinauer Associates, Inc, 722 pp.

Chizinski C.J. (2007) Life-history and Morphological Variation in Stunted and Non-stunted Fish. PhD Dissertation, Lubbock, TX: Texas Tech University, $171 \mathrm{pp}$.

Choi Y.D. (2004) Theories for ecological restoration in changing environment: toward 'futuristic' restoration. Ecological Research 19, 75-81.
Dahlberg M. (1979) A review of survival rates of fish eggs and larvae in relation to impact assessments. Marine Fisheries Review 41, 1-12.

Donald D.B. \& Alger D.J. (1989) Evaluation of exploitation as a means of improving growth in a stunted population of brook trout. North American Journal of Fisheries Management 9, 177-183.

Ellis M.M. \& Elphick C.S. (2007) Using a stochastic model to examine the ecological, economic and ethical consequences of population control in a charismatic invasive species: mute swans in North America. Journal of Applied Ecology 44, 312-322.

Everett R.A. (2000) Patterns and pathways of biological invasions. Trends in Ecology \& Evolution 15, 177-178.

Govindarajulu P., Altwegg R. \& Anholt B.R. (2005) Matrix model investigation of invasive species control: bullfrogs on Vancouver Island. Ecological Applications 15, 2161-2170.

van Groenendael J., de Kroon H., Kalisz S. \& Tuljapurkar S. (1994) Loop analysis: evaluating life history pathways in population projection matrices. Ecology 75, 2410-2415.

Hergenrader G.L. \& Bliss Q.P. (1971) The white perch in Nebraska. Transactions of the American Fisheries Society 100, 734-738.

Hulme P.E. (2006) Beyond control: wider implications for the management of biological invasions. Journal of Applied Ecology 43, 835-847.

Imre I., Grant J.W.A. \& Cunjak R.A. (2005) Densitydependent growth of young-of-the-year Atlantic salmon Salmo salar in Catamaran Brook, New Brunswick. Journal of Animal Ecology 74, 508-516.

Jackson L.F. \& Sullivan C.V. (1995) Reproduction of white perch - the annual gametogenic cycle. Transactions of the American Fisheries Society 124, 563-577.

Klemetsen A., Amundsen P.A., Grotnes P.E., Knudsen R., Kristoffersen R. \& Martin A. (2002) Takvatn through 20 years: long-term effects of an experimental mass removal of Arctic charr, Salvelinus alpinus, from a subarctic lake. Environmental Biology of Fishes 64, 39-47.

van Kooten T., Persson L. \& de Roos A. (2007) Sizedependent mortality induces life-history changes mediated through population dynamical feedbacks. American Naturalist 170, 258-270.

de Kroon H., van Groenendael J. \& Ehrlen J. (2000) Elasticities: a review of methods and model limitations. Ecology 81, 607-618.

Madenjian C.P., Knight R.L., Bur M.T. \& Forney J.L. (2000) Reduction in recruitment of white bass in Lake Erie after invasion of white perch. Transactions of the American Fisheries Society 129, 1340-1353.

Malakoff D. (1999) Biological control: fighting fire with fire Australian biocontrol beats rabbits, but not rules. Science 285, 1841-1843. 
Pierce R.B., Tomcko C.M. \& Margenau T.L. (2003) Density dependence in growth and size structure of northern pike populations. North American Journal of Fisheries Management 23, 331-339.

Prout M.W., Mills E.L. \& Forney J.L. (1990) Diet, growth, and potential competitive interactions between age- 0 white perch and yellow perch in Oneida Lake, New York. Transactions of the American Fisheries Society 119, 966-975.

Ricker W. (1975) Computation and interpretation of biological statistics of fish populations. Bulletin of the Fisheries Research Board of Canada 91, 1-382.

Roff D.A. (1983) An allocation model of growth and reproduction in fish. Canadian Journal of Fisheries and Aquatic Sciences 40, 1395-1404.

Roff D.A. (1992) The Evolution of Life Histories: Theory and Analysis. New York: Chapman and Hall, 535 pp.

Salek S.J., Godwin J., Sullivan C.V. \& Stacey N.E. (2001) Courtship and tank spawning behavior of temperate basses (Genus Morone). Transactions of the American Fisheries Society 130, 833-847.

Schaeffer J.S. \& Margraf F.J. (1987) Predation on fish eggs by white perch, Morone americana, in western Lake Erie. Environmental Biology of Fishes 18, 77-80.

Shea K., Sheppard A. \& Woodburn T. (2006) Seasonal lifehistory models for the integrated management of the invasive weed nodding thistle Carduus nutans in Australia. Journal of Applied Ecology 43, 517-526.

Shields J.T. (1958) Experimental control of carp reproduction through water drawdowns in Fort Randall Reservoir, South Dakota. Transactions of the American Fisheries Society 87, 23-33.
Simberloff D., Parker I.M. \& Windle P.N. (2005) Introduced species policy, management, and future research needs. Frontiers in Ecology and the Environment 3, 12-20.

Simonović P.D. \& Nikolić V.P. (2007) Density-dependence of growth characteristics and maturation in stream-dwelling resident brown trout, Salmo trutta, in Serbia. Fisheries Management and Ecology 14, 1-6.

Taub S.H. (1969) Fecundity of the white perch. The Progressive Fish Culturist 31, 166-168.

Vaughan D.S. \& Saila S.B. (1976) A method for determining mortality rates using the Leslie matrix. Transactions of the American Fisheries Society 105, 380-383.

Vrtiska L.A., Jr , Peters E.J. \& Porath M.T. (2003) Flathead catfish habitat use and predation on a stunted white perch population in Branched Oak Reservoir, Nebraska. Journal of Freshwater Ecology 18, 605-613.

Wardle G.M. (1998) A graph theory approach to demographic loop analysis. Ecology 79, 2539-2549.

Wilde G.R. \& Durham B.W. (2008) Daily survival rates for juveniles of six Great Plains cyprinid species. Transactions of the American Fisheries Society 137, 830-833.

Wong R.K. (2002) White Perch Expansion and Life History within a Southern Reservoir. MSc Thesis, Raleigh, NC: North Carolina State University, 66 pp.

Ylikarjula J., Heino M. \& Dieckmann U. (1999) Ecology and adaptation of stunted growth in fish. Evolutionary Ecology 13, 433-453.

Zuerlein G. (1981) The white perch, Morone americana (Gmelin) in Nebraska. Nebraska Technical Series No. 8. 108 pp. 